\title{
Washback of IELTS on the Assumption College English Program
}

\author{
SUCHADA SANONGUTHAI \\ Assumption College Thonburi, Thailand
}

\section{Bio Data:}

Suchada Sanonguthai, is the head of the English Program Academic Department at Assumption College Thonburi. In 2005, she was selected to represent Thailand in the AFS (American Field Service) Visiting Teacher Program at Montpelier High School in Montpelier, Vermont.

\begin{abstract}
This paper reports and discusses how the IELTS test has brought its impact to Assumption College Thonburi English Program (ACTEP)'s exit testing, English courses offered and foreign teachers' teaching. Two different methods of data collection apply; an interview with the ACTEP Academic Head and questionnaire for Grades 10-11 students and foreign teachers. It has been found that in order to assure Grade 12 performance on the IELTS test, other well-known achievement tests have been put into the ACTEP academic policy. IELTS preparatory courses have been listed into the Grades 10- 12 ACTEP curriculum. The findings show that the foreign teachers, both Native-English speakers and Non-Native English speakers teaching staff in the ACTEP, need more insights to the IELTS test format. It is also well worth recommending that students need to practice more during their high school years as their Grade 11exit test, the CU-TEP test, cannot reflect all strategies needed in the IELTS test.
\end{abstract}

Keywords: IELTS, English Program, exit testing, ESOL, CU-TEP

\section{Introduction}

Assumption College Thonburi (ACT), a private school officially established in 1961, has been serving 5,208 students altogether from Grades 1-12 with a variety of academic programs. In the academic year $2010^{1}$ there are 294 Thai

\footnotetext{
1 Thailand's academic year starts in the middle of May and ends in early March of the following year.
} 
teachers and 60 foreign teachers working for ACT. The two main programs at ACT are as follows:

Program 1: Bilingual Program which offers three core subjects including English, Science and Mathematics; partly taught in English by foreign teachers and partly taught in Thai by Thai teachers.

Program 2: English Program which offers English, Mathematics, Science, Music, Basic Vocational, Physical Education and Health Education taught in English by foreign teachers, accompanied by Thai teachers.

Assumption College Thonburi English Program (ACTEP) was established in the academic year 2006, starting with Grade 1, Grade 4 and Grade 7. In the academic year 2009 ACTEP Grade 10 was begun for Grade 9 students of that year. Currently in the academic year 2010, Grades 1- 11 are being operated, and ACTEP will have its completion of Grade 12 in May 2011. English is used as the medium of teaching in the six subject groups; namely, Mathematics, English, Science, Health and Physical Education, Career and Technology and Music based on the Ministry of Education Curriculum 2554 B.E.

\section{Numbers of Classes, Students and Teachers in the Academic Year 2010}

The two tables below show the number of students enrolled and foreign teachers working in ACTEP in the academic year 2010. 
Table 1

Number of ACTEP students in the academic year 2010

\begin{tabular}{|l|c|c|c|c|}
\hline Grade & $\begin{array}{c}\text { Section } \\
\mathrm{A}\end{array}$ & $\begin{array}{c}\text { Section } \\
\mathrm{B}\end{array}$ & $\begin{array}{c}\text { Section } \\
\text { C }\end{array}$ & $\begin{array}{c}\text { Total } \\
\text { Number }\end{array}$ \\
\hline $\begin{array}{l}\text { Grade } \\
1\end{array}$ & 30 & 30 & 0 & 60 \\
\hline $\begin{array}{l}\text { Grade } \\
2\end{array}$ & 30 & 30 & 30 & 90 \\
\hline $\begin{array}{l}\text { Grade } \\
3\end{array}$ & 30 & 30 & 0 & 60 \\
\hline $\begin{array}{l}\text { Grade } \\
4\end{array}$ & 30 & 30 & 0 & 60 \\
\hline $\begin{array}{l}\text { Grade } \\
5\end{array}$ & 28 & 27 & 0 & 55 \\
\hline $\begin{array}{l}\text { Grade } \\
6\end{array}$ & 29 & 29 & 0 & 58 \\
\hline
\end{tabular}

\begin{tabular}{|l|c|c|c|}
\hline Grade & $\begin{array}{c}\text { Section } \\
\mathrm{A}\end{array}$ & $\begin{array}{c}\text { Section } \\
\mathrm{B}\end{array}$ & $\begin{array}{c}\text { Total } \\
\text { Number }\end{array}$ \\
\hline $\begin{array}{l}\text { Grade } \\
7\end{array}$ & 30 & 30 & 60 \\
\hline $\begin{array}{l}\text { Grade } \\
8\end{array}$ & 30 & 30 & 60 \\
\hline $\begin{array}{l}\text { Grade } \\
9\end{array}$ & 28 & 28 & 56 \\
\hline $\begin{array}{l}\text { Grade } \\
10\end{array}$ & 25 & 25 & 50 \\
\hline $\begin{array}{l}\text { Grade } \\
11\end{array}$ & 18 & 20 & 38 \\
\hline
\end{tabular}

Each grade consists of two sections, Section A and Section B, except for Grade 2, which consists of three sections due to the availability of one extra classroom in the academic year 2009. Maximum number of students in each section is 30 as required by the Ministry of Education of Thailand.

Table 2

Number of grades 1-11 ACTEP foreign teachers in the academic year 2010

\begin{tabular}{|l|c|c|c|}
\hline \multicolumn{1}{|c|}{ Strand } & $\begin{array}{c}\text { Native- } \\
\text { English } \\
\text { Teachers }\end{array}$ & $\begin{array}{c}\text { Non-Native } \\
\text { English } \\
\text { Teachers }\end{array}$ & $\begin{array}{c}\text { Total } \\
\text { Number } \\
\text { of Foreign } \\
\text { Teachers }\end{array}$ \\
\hline Mathematics & 3 & 4 & 7 \\
\hline $\begin{array}{l}\text { Science (including Biology, } \\
\text { Physics and Chemistry) }\end{array}$ & 1 & 7 & 8 \\
\hline English & 5 & 0 & 5 \\
\hline $\begin{array}{l}\text { Physical and Health } \\
\text { Education }\end{array}$ & 1 & 1 & 2 \\
\hline Music & 1 & 1 & 2 \\
\hline Career and Technology & 1 & 1 & 2 \\
\hline
\end{tabular}




\begin{tabular}{|l|l|l|l|}
\hline Total Number of teachers & 12 & 14 & 26 \\
\hline
\end{tabular}

Foreign Teachers in the English Program are required to obtain at least their Bachelor Degree in related teaching before they apply to teach at ACTEP. Non-Native English teachers are required to pass at least IELTS score 7.0, TOEFL score 580 paper-based and TOEIC score 750 before they can be employed to teach in ACTEP. Every foreign teacher is assigned to be a club advisor for ACTEP students. Thai teachers are assigned to coordinate in different subject areas, but not to teach class.

\section{ACTEP Grades 1-12 Curriculum Structure}

The following tables shows number of periods (one period is 50 minutes long) spent on the eight core courses, supplementary courses and student development activities taught in English and Thai in the ACTEP's primary levels, lower-secondary levels and higher-secondary levels. Please note that for higher secondary levels, Grades 10-11; Section A and Sections B are on different strands due to their different subject focuses as shown in Tables 3-5.

Table 3

ACTEP grades 1-6 curriculum structures

\begin{tabular}{|l|c|c|c|}
\hline \multirow{2}{*}{ Strand } & $\begin{array}{l}\text { Language } \\
\text { employed } \\
\text { in class }\end{array}$ & \multicolumn{2}{|l|}{$\begin{array}{l}\text { Number of Periods: } \\
\text { Week }\end{array}$} \\
\cline { 3 - 4 } & & Grades 1-3 & Grades 4-6 \\
\hline Core Courses & & & 6 \\
\hline 1. Mathematics & English & 5 & 4 \\
\hline 2. Science & English & 4 & 5 \\
\hline 3. English (Four-Skill English) & English & 5 & 1 \\
\hline $\begin{array}{l}\text { 4. Health and Physical } \\
\text { Education } \\
\text { 4.1 Health Education }\end{array}$ & English & 1 & 1 \\
\hline 4.2 Physical Education & English & 1 & \\
\hline
\end{tabular}




\begin{tabular}{|c|c|c|c|}
\hline $\begin{array}{l}\text { 5. Art } \\
\text { 5.1 Visual art and Thai } \\
\text { Performing Art }\end{array}$ & Thai & 1 & 1 \\
\hline 5.2 Music & English & 1 & 1 \\
\hline $\begin{array}{l}\text { 6. Career and Technology } \\
\text { 6.1 Home Economics }\end{array}$ & English & 1 & 1 \\
\hline 6.2 Computer & Thai & 1 & 1 \\
\hline $\begin{array}{l}\text { 7. Social studies } \\
\text { 7.1 Social studies, Religions } \\
\text { and Cultures }\end{array}$ & Thai & 2 & 2 \\
\hline 7.2 History & Thai & 1 & 1 \\
\hline 8. Thai & Thai & 5 & 4 \\
\hline Total Numbers of Periods & & 28 & 28 \\
\hline \multicolumn{4}{|l|}{ Supplementary Course } \\
\hline 1. Computer & Thai & 1 & 1 \\
\hline Total Number of Periods & & 1 & 1 \\
\hline \multicolumn{4}{|l|}{$\begin{array}{l}\text { Student Development } \\
\text { Activities }\end{array}$} \\
\hline $\begin{array}{l}\text { 1. Ethics/Homeroom } \\
\text { (Guidance Counseling) }\end{array}$ & Thai & 2 & 1 \\
\hline \multicolumn{4}{|l|}{ 2. Potential Development } \\
\hline 2.1 Reading Activities & Thai & 1 & 1 \\
\hline 2.2 Students' Club & English & 0 & 1 \\
\hline 2.3 Scout & Thai & 1 & 1 \\
\hline 2.4 Chinese & $\begin{array}{l}\text { Thai and } \\
\text { Chinese }\end{array}$ & 2 & 2 \\
\hline Total Number of Periods & & 6 & 6 \\
\hline $\begin{array}{l}\text { Numbers of Classes taught in } \\
\text { English per week }\end{array}$ & & 18 & 18 \\
\hline $\begin{array}{l}\text { Numbers of Classes taught in } \\
\text { Thai per week }\end{array}$ & & 16 & 16 \\
\hline $\begin{array}{l}\text { Numbers of Classes taught in } \\
\text { Thai and Chinese per week }\end{array}$ & & 1 & 1 \\
\hline $\begin{array}{l}\text { Total Numbers of Periods per } \\
\text { week }\end{array}$ & & 35 & 35 \\
\hline
\end{tabular}

Table 4

ACTEP Grades 7-9 Curriculum Structures

\begin{tabular}{|c|l|l|}
\hline Strand & $\begin{array}{l}\text { Language } \\
\text { employed }\end{array}$ & $\begin{array}{l}\text { Number of Periods: } \\
\text { Week }\end{array}$ \\
\hline
\end{tabular}




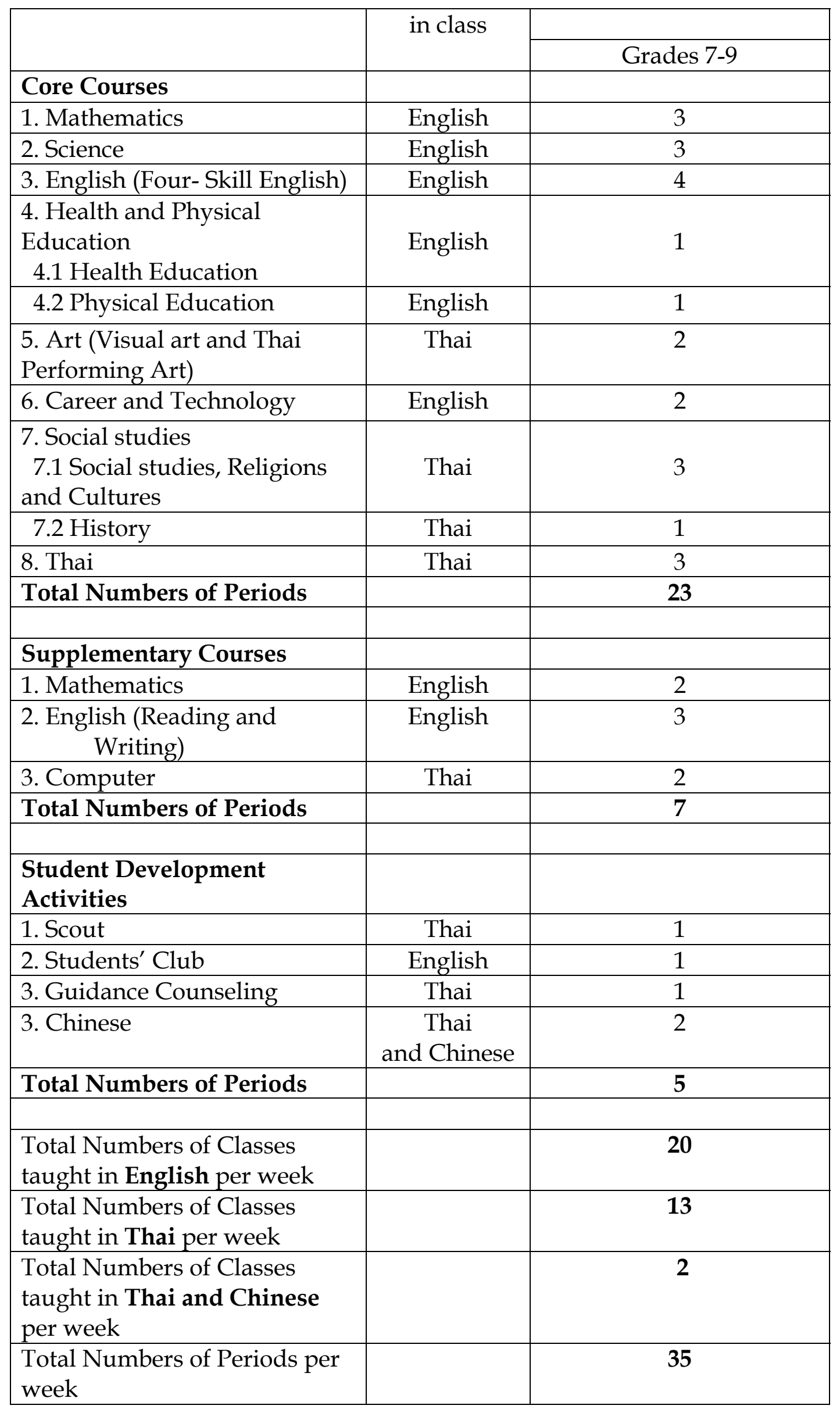


Table 5

ACTEP grades 10-12 Science-Mathematics focus (section A) program and grades 10-

11 Mathematics-English focus (section B) program curriculum structures

\begin{tabular}{|c|c|c|c|}
\hline \multirow{2}{*}{ Strand } & \multirow{2}{*}{$\begin{array}{l}\text { Language } \\
\text { employed } \\
\text { in class }\end{array}$} & \multicolumn{2}{|c|}{ Number of Periods: Week } \\
\hline & & $\begin{array}{c}\text { Grades } 10-12 \\
\text { (Section A) }\end{array}$ & $\begin{array}{c}\text { Grades 10-12 } \\
\text { (Section B) }\end{array}$ \\
\hline \multicolumn{4}{|l|}{ Core Courses } \\
\hline 1. Mathematics & English & 2 & 2 \\
\hline 2. Science & English & 2 & 2 \\
\hline 3. English & English & 2 & 2 \\
\hline $\begin{array}{l}\text { 4. Health and Physical } \\
\text { Education } \\
\text { 4.1 Health Education }\end{array}$ & English & 1 & 1 \\
\hline 4.2 Physical Education & English & 1 & 1 \\
\hline $\begin{array}{l}\text { 5. Art (Visual art and Thai } \\
\text { Performing Art) }\end{array}$ & Thai & 1 & 1 \\
\hline 6. Career and Technology & English & 1 & 1 \\
\hline $\begin{array}{l}\text { 7. Social studies } \\
\text { 7.1 Social studies, Religions } \\
\text { and Cultures }\end{array}$ & Thai & 2 & 2 \\
\hline 7.2 History & Thai & 1 & 1 \\
\hline 8. Thai & Thai & 2 & 2 \\
\hline Total Numbers of Periods & & 15 & 15 \\
\hline \multicolumn{4}{|l|}{ Supplementary Courses } \\
\hline 1. Mathematics & English & 3 & 3 \\
\hline $\begin{array}{l}\text { 2. English (IELT Preparatory } \\
\text { Course) }\end{array}$ & English & 2 & 2 \\
\hline 3. Computer & Thai & 2 & 2 \\
\hline 4. Physics & English & 3 & 0 \\
\hline 5. Chemistry & English & 3 & 0 \\
\hline 6. Biology & English & 3 & 0 \\
\hline 7. Thai & Thai & 0 & 1 \\
\hline 8. Social Studies & Thai & 0 & 2 \\
\hline 9. English (Academic Writing) & English & 0 & 5 \\
\hline 10. Music & English & 0 & 1 \\
\hline Total Numbers of Periods & & 16 & 16 \\
\hline $\begin{array}{l}\text { Student Development } \\
\text { Activities }\end{array}$ & & & \\
\hline
\end{tabular}




\begin{tabular}{|l|c|c|c|}
\hline $\begin{array}{l}\text { 1. Military Practice/ } \\
\text { Community-Service Activities }\end{array}$ & Thai & 2 & 2 \\
\hline 2. Students' Club & English & 1 & 1 \\
\hline 3. Guidance Counseling & Thai & 1 & 1 \\
\hline Total Number of Periods & & $\mathbf{4}$ & $\mathbf{4}$ \\
\hline $\begin{array}{l}\text { Numbers of Classes taught in } \\
\text { English per week }\end{array}$ & $\mathbf{2 4}$ & $\mathbf{2 1}$ \\
\hline $\begin{array}{l}\text { Numbers of Classes taught in } \\
\text { Thai per week }\end{array}$ & $\mathbf{1 1}$ & $\mathbf{1 4}$ \\
\hline $\begin{array}{l}\text { Total Numbers of Periods per } \\
\text { week }\end{array}$ & $\mathbf{3 5}$ & $\mathbf{3 5}$ \\
\hline
\end{tabular}

Thus, as per the three curriculum structures above, English is used as the medium of teaching in more than half of each class time each week. English language, along with course material published or written in English is required during the students' scheduled class time, 51.42 percent in Grades 1-6, 57.14 percent in Grades 7-9, 68.57 percent in Grades 10-12 section A and 60.00 percent in Grades 10-12 section B.

\section{IELTS as a Grade 12 Exit Test at ACTEP}

It was not until 2009 that ACTEP applied the minimum score of IELTS 5.5 as required by the Ministry of Education. This policy applies to every school in Thailand where English Program teaching in Grades 10-12 English is permitted to be conducted. The consequence of not being able to pass the cutoff score is that the school will not be able to certify that the student attended the English Program. It can only be said that they graduated from Assumption College Thonburi bilingual program where Thai is mainly used in class. This can lessen their chance of being accepted into prestigious international institutions both in and outside Thailand. The equivalent tests of 
the minimum score of IELTS 5.5 can be TOEFL score of 550 (paper-based) and TOEIC score of 650 .

\section{Washback of IELTS on Exit Testing, Grades 10- 11 English Courses Offered and Teacher Teaching at ACTEP}

In studying how IELTS has brought its impact to Assumption College Thonburi English program ACT exit testing, English courses offered in Grades 10-11 and foreign teachers' teaching. Two different methods of data collection apply; an interview with the ACTEP Academic Head and questionnaire for Grades 10-11 students and foreign teachers.

\section{Washback of IELTS on Other ACTEP Exit Tests}

An interview with the ACTEP academic Head was conducted to find out how IELTS affects the English exit testing at ACTEP. The interviewee is 32 years old and had started teaching Grade 10 English in the bilingual program in 2001 before she became an ACTEP Thai Main Coordinator in the academic year 2006 and the ACT Academic Head in 2008 until present. The interview focused on how ACTEP has been keeping track of student's English proficiency from Grade 1 to Grade 11.

The interview reveals that starting from the academic year 2009 in order to assure Grade 12 performance on the IELTS test, other well-known achievement English tests have been put into the ACTEP academic policy. Different exams of University of Cambridge English for Speakers of Other Languages (ESOL) as set as exit tests at the end of Grades 2, 4, 6, 8, 9. In Grade 10 and 11 as shown in the table: 
Table 6

ACTEP English Exit Tests

\begin{tabular}{|c|c|}
\hline Grade & Exit Test \\
\hline Grade 2 & Starters with minimum Pass score \\
\hline Grade 4 & Movers with minimum Pass score \\
\hline Grade 6 & Flyers with minimum Pass score \\
\hline Grade 8 & Key English Test (KET) with minimum Pass score \\
\hline Grade 9 & Preliminary English Test with Pass score \\
\hline Grade 10 & $\begin{array}{c}\text { Chulalongkorn University Test of English } \\
\text { Proficiency (CU-TEP) at the score of 450 }\end{array}$ \\
\hline Grade 11 & CU-TEP at the score of 500 \\
\hline Grade 12 & $\begin{array}{r}\text { IELTS (Academic Band) } \\
\text { at the score of 5.5 on overall band }\end{array}$ \\
\hline
\end{tabular}

It is worth noting that the Chulalongkorn University test of English Proficiency, (CU-TEP), is adopted at ACTEP as an exit test in Grade 10 and Grade 11 before the students take their IELTS in Grade 11 next school year. Chulalongkorn University Test of English Proficiency (CU-TEP) has been widely recognized nationwide among Thai higher secondary students and Thai and Non-Thai undergraduates who would like to apply for CU graduate schools and CU international programs.

One of the most important reasons which leads ACTEP to employ this test as an exit test is the practicality of CU-TEP. The students can apply for CU-TEP at any month of the year depending on their time availability. Test takers can access CU-TEP test schedules and register for a test online by visiting http://www.atc.chula.ac.th. The CU-TEP test fee is 600 baht. The test components are taken in the following order:

\begin{tabular}{|c|l|c|c|}
\hline Skills tested & Specific features & $\begin{array}{c}\text { Number of } \\
\text { items }\end{array}$ & Time allocated \\
\hline Listening & Short Dialog & 30 & 30 minutes \\
\hline
\end{tabular}




\begin{tabular}{|c|l|c|c|}
\hline & $\begin{array}{l}\text { Long Dialog } \\
\text { Monolog }\end{array}$ & 60 & 70 minutes \\
\hline Reading & $\begin{array}{l}\text { Cloze reading } \\
\text { Short text } \\
\text { Long text }\end{array}$ & 30 & 30 minutes \\
\hline Writing & Error Identification & $\mathbf{1 2 0}$ & $\mathbf{1 6 0}$ minutes \\
\hline & Total &
\end{tabular}

Students who are not able to pass any of the exit tests will be required to pay extra tuition fees to take an extra English foundation course during their 4-week summer school in March in order to try to pass the equivalent exit test of their grade level. These exit tests, according to the interviewee, help keep track of the student's progress in their English proficiency before they take IELTS during their Grade 12 year.

Even though the IELTS test is an exit test for the Grade 12 student, the Chulalongkorn University Test of English Proficiency (CU-TEP) is selected to be an exit test for both Grades 10 and 11 students. One of the two reasons is the practicality of CU-TEP, which the students can apply for at any month of the academic year depending on their time availability. The second reason is that the CU-TEP can offer a testing on three main components of English proficiency: listening, reading and writing which are mostly identical with IELTS except for the CU-TEP Writing Section.

According to Bemmel and Tucker (2011), there are some particular skills and strategies needed to ensure the success of IELTS talking. Those required skills and strategies are as follows:

\section{Listening Skills}

1. Understanding the instructions

2. Previewing and Predicting 
3. Listening for specific information

4. Checking and rewriting

\section{Reading Skills}

5. Previewing

6. Interpreting the instructions and questions

7. Scanning the text for specific answers

8. Checking their answers

\section{Writing Skills}

9. Preparation

10. Writing

11. Editing

\section{Speaking Skills}

12. Introduction and interview

13. Individual long run (extended speaking)

14. Two-way discussion

The following extracts of CU-TEP are taken from Chulalongkorn University's CU-TEP practice book (2004).

Sample Questions from the CU-TEP Listening Section's Short Dialog

On the CD, students will hear 


\section{TAPESCRIPT \\ FORM A}

You will be tested on your ability to understand spoken English. There are three sections, each with its own directions. If you wish, you may take notes.

\section{PART I}

Instructions: You will hear short dialogues between two people, after which, a question will be asked. You will hear each dialogue only once. After hearing the dialogue and question, select from the four choices that which best answers the question.

Question 1. W: Excuse me, could you tell me if there's a bank on campus?

M: I'm sorry. It's my first day here too.

(narrator) Who are the two speakers?

Question 2. M: Do you mind if I borrow your car tonight?

W: Not at all, as long as you return it in one piece.

(narrator) What does the woman mean?

Question 3. W: How was dinner with your in-laws, John?

M: They hardly spoke to me the whole time. It was as if I weren't there!

(narrator) What happened at the dinner?

Question 4. M: How did you like the film last night?

W: I've seen better.

(narrator) What does the woman mean?

Question 5. W: People from work are having a get together this weekend.

Can you come?

M: Can I let you know? I might have to work out of town then.

(narrator) What does the man mean? 
Students will read and answer the following questions on their answer sheet.

\section{CU-TEP LISTENING PRACTICE TEST FORM A}

You will be tested on your ability to understand spoken English. There are three sections, each with its own directions. If you wish, you may take notes.

\section{PART I}

Instructions: You will hear short dialogues between two people, after which, a question will be asked. You will hear each dialogue only once. After hearing the dialogue and question, select from the four choices that which best answers the question.

1. 1. Two students

2. A student and a teacher

3. A customer and a receptionist

4. A customer and a bank officer

2. 1. She doesn't want to lend the man her car.

2. The man should return her car in one hour.

3. She wants the man to be careful with her car.

4. The man may have her car as long as he wants.

3. 1. John's in-laws did not serve him.

2. John's in-laws made him feel good.

3. John's in-laws ignored him completely.

4. John's in-laws did not show up for dinner.

4. 1. The film was not good.

2. She had seen it before.

3. She couldn't see it clearly.

4. The film was very interesting.

5. 1. He is not sure if he will be free.

2. He wants to go with the woman.

3. He is not free to come to the get together this weekend.

4. He doesn't want to get together with people from work. 


\section{Sample Questions from the CU-TEP Listening Section's Long Dialog}

On the CD, students will hear

\section{PART II}

Instructions: In this section you will hear longer dialogues between two people. After each dialogue questions will be asked. You will hear each dialogue only once. After hearing the dialogue and each question, select from the four choices that which best answers the question.

\section{Conversation 1}

M: Sarah, your eyes are red. What's the matter?

W: I couldn't sleep last night. My neighbours are a pain.

M: Oh yeah? What did they do?

W: Well, last night they were having some kind of party that went on all night! The music was so loud.

M: Why didn't you complain, then? Better still, you could have called the police. I'm sure it is against the law to disturb neighbours, especially at those hours.

W: But they would know it was me who had called the police.

M: So? What can they do? Are you afraid of hurting their feelings or what? Those inconsiderate people deserve a visit by the police.

W: I didn't tell you. My professor lives there.

Question 16. Why did the woman have red eyes?

Question 17. What is the man's advice to the woman?

Question 18. Why might the woman not follow his advice?

Students will read and answer the following questions on their answer sheet. 


\section{PART II}

Instructions: In this section you will hear longer dialogues between two people. After each dialogue questions will be asked. You will hear each dialogue only once. After hearing the dialogue and each question, select from the four choices that which best answers the question.

\section{Conversation 1}

16. 1. She did not sleep well.

2. She went to a party all night.

3. Her neighbours hurt her feelings.

4. She was working on her report all night.

17. 1. Inform the police

2. Complain to her neighbours

3. Visit her doctor about the pain

4. Seek advice from her professor

18. 1. She thinks it might be painful.

2. She is not sure if it's against the law.

3. She is afraid of upsetting her professor.

4. She does not want to hurt anyone's feelings.

\section{Sample Questions from the CU-TEP Listening Section's Monolog}

On the CD, students will hear

\section{PART III}

Instructions: You will now hear two short talks. After each talk you will be asked some questions. You will hear each talk only once. After hearing the talk and each question, select from the four choices that which best answers the question.

\section{Talk I}

Ecotourism sounds a nice idea, I'm sure you agree, but is it commercially viable? Conservation Corporation Africa, or CCA for short, seems to suggest it is. The company's mission is to attract international investors and show that capitalism and conservation can work hand in hand.

CCA was founded in 1990 by two entrepreneurs, Dave Varty and Alan Bernstein, to provide for luxury ecotourism. Seventeen properties later, it's safe to say that their mission has succeeded. They started in South Africa, but now they have facilities in Kenya, Zimbabwe and Tanzania as well. The next stop is going to be Botswana.

First, there's the luxury aspect of course: camp size is limited, lodges are beautifully appointed and perfectly integrated into the surroundings, the cuisine is sophisticated with a Pan-African theme. The group's properties have been called 'the Aman resorts of Africa'.

But there's also the commitment to the community. Around each property they'll train local workers, help to provide local social services, that's mostly clinics and schools, and they also encourage small businesses nearby. Their lodges look very distinctive and that's partly because they insist on employing local workers and using traditional techniques when possible.

So who says you can't make money and have a social or environmental mission at the same time? 
Students will read and answer the following questions on their answer sheet.

\section{PART III}

Instructions: You will now hear two short talks. After each talk you will be asked some questions. You will hear each talk only once. After hearing the talk and each question, select from the four choices that which best answers the question.

\section{Talk I}

25. 1. Education

2. Ecotourism

3. Environment

4. Entrepreneurs

26. 1. Asia

2. Africa

3. America

4. Antarctica

27. 1. Food

2. Service

3. Climate

4. Accommodation 


\section{Sample Questions from the CU-TEP Reading Section's Long Text}

\section{PART IV}

Taking vitamin $\mathrm{C}$ can reduce death rates by as much as 42 per cent for men and 10 per cent for women who have taken it in high doses, a study released on Thursday showed.

The study by the UCLA School of Public Health, to be published

$5 \quad$ Friday in the journal Epidemiology, found a strong relationship between increasing doses of vitamin $\mathrm{C}$ and a reduction in cardiovascular disease.

In a 10-year follow-up study of 11,348 US adults, researchers found that men who took relatively high doses of vitamin $\mathrm{C}$ were 45 per cent less likely to die of heart disease than men in the lowest intake

10 group, while women were 25 per cent less likely to die of heart disease than those who ingested little vitamin $\mathrm{C}$.

The researchers noted that claims that vitamin $\mathrm{C}$ improves health are not new. Vitamin C, which is found naturally in citrus fruits, potatoes and leafy vegetables, is often taken in tablet form to prevent

15 ailments from scurvy to the common cold.

But earlier data on long-term health effects of high intake of the vitamin have been sparse and inconclusive, they said.

They cited the UCLA study as the most comprehensive to date because it factors in age and sex of the subjects and a number of other

20 variables, such as smoking and medical history.

The researchers concluded that their findings support earlier indications that high levels of vitamin $\mathrm{C}$ and other antioxidant vitamins, such as $\mathrm{A}$ and $\mathrm{E}$, reduce the risk of arteriosclerosis, or hardening of the arteries.

25 They also said the new research lends support to previously documented trends showing higher consumption of vitamin $\mathrm{C}$ and significant declines in age-adjusted death rates that are only partly explained by declines in smoking and cholesterol levels.

Surveys have shown that about one fourth of all US adults take

30 vitamin supplements daily and about half use them less regularly. Vitamin $\mathrm{C}$ is the most common of all supplements and is the nutrient most likely to be consumed in quantities greatly exceeding the Recommended Dietary Allowance of $60 \mathrm{mg}$ per day.

For the UCLA study, researchers looked back at examination

35 records from 1971 to 1974 for the group of adults aged 25-74 and followed up for mortality through 1984 . In that time, 1,809 people in the sampling died.

The highest intake group studied took daily supplements containing vitamin $\mathrm{C}$, primarily in the form of multi-vitamin pills. Most of those people took several hundred milligrams a day of vitamin $\mathrm{C}$. 
61. The population used in the research is

1. non-smoking adults of all ages

2. adults with different health problems

3. adults of both sexes and different ages

4. children as well as adults of both sexes

62. According to the finding of the UCLA study, vitamin C may

1. prolong life

2. affect ingestion

3. reduce cholesterol levels

4. increase cardiovascular disease

63. What is TRUE about vitamin C?

1. It is not recommended for those who have cholesterol problems.

2. If taken at high levels, it may increase the risk of arteriosclerosis.

3. It can be taken in the form of pills as well as from natural sources.

4. Like other antioxidant vitamins, it has both advantages and disadvantages.

64. The UCLA study was claimed as the most comprehensive because it

1. was conducted over 10 years

2. requires both time and hard work

3. reports new and very useful findings

4. contains various subjects and other health-related factors

65. From the UCLA study, the figure 1,809 (line 36) indicates

1. a low death rate

2. a high death rate

3. nothing conclusive

4. deaths resulting from vitamin $\mathrm{C}$ overdose

66. "Scurvy" (line 15) is a kind of
1. disease
2. mineral
3. nutrient
4. vegetable

67. The word "sparse" (line 17) is close in meaning to
1. complete
2. confusing
3. informative
4. insufficient 


\section{Sample Questions from the CU-TEP Writing Section WRITING}

\section{Writing I:}

Each item in this part consists of a sentence with four parts underlined. Select the part $(1,2,3$ or 4$)$ which is incorrect.

91. Besides proving to be a virtual gold mine for food sources, oceans hold 12

the answer to questions about the historically development of both life 3 and planet.

92. Thailand should focus on building up the domestic market and cooked 12 chicken exports while waiting a future opportunity to re-enter the fresh 3 4 chicken market.

93. "Sriburapa" or Kularb Saipradit is remembered as a thinker, a journalist<smiles>[3H][V]</smiles>
and a fight for human rights. 3

It is expected that the students' test results of the CU-TEP can reflect how good the students are at listening, reading and necessary grammar in writing to be used in the IELTS testing. However, CU-TEP does not include a speaking part in their exam due to the fact that it is an inexpensive English proficiency test, compared to other tests like IELTS and TOEFL.

\section{Washback on Grades 10-11 English Courses Offered at ACTEP}

According to the ACTEP Grades 10-12 curriculum structure in Table 5, both Section A and Section B of Grades 10 and 12 have to study the 4-skill English as their core course and the IELTS preparatory course as their supplementary 
course. In Grades 10-11 the English four-skill textbook Traveller (2009) series is selected for Grades 10- 11 core English courses. The IELTS Express (2006) series is the main course material for supplementary English course.

\section{Data collection}

In finding how CU-TEP and IELTS have influenced the ACTEP Grades 10-11 English Courses offered, the below questionnaire was given to 39 ACTEP students in Grade 10 and 38 ACTEP students in Grade 11.

\section{Questionnaire for Grades 10-11}

\section{Assumption College Thonburi English Program (ACTEP) Students.}

This questionnaire is to find out how the following facts are perceived by Grades 10-11 ACTEP students.

1. All of the students are required to pass either TOEFL at the score of 550 (paper-based) or IELTS at the score of 5.5 on overall band during your Grade 12 study at Assumption College Thonburi.

2. CU-TEP (Chulalongkorn University Test of English Proficiency) is used as the main English proficiency test in Grades 10-11 in the academic year 2009 and 2010 .

3. The ways that different subjects including Mathematics, Basic Science, Additional Science, Health and Physical Education, Music and Career and Technology are taught in English and that English courses are designed by having Class A (Science-Maths students) take a 4-skill English course (5 periods/week) and an IELTS preparatory course (2 periods/week) and having Class B (Maths-English students) take a 4-skill English course (5 
periods/week), an IELTS preparatory course (2 periods/week), and an academic writing courses (4 periods/week) during regular classes MondaysFridays.

Please answer these background questions:

1. I have been in ACTEP for years and months.

2. For undergraduate program I wish to study in (name of faculty) (name of the institution) (please

circle the language employed as the medium of teaching)

Thai English

\begin{tabular}{|c|c|c|c|c|c|}
\hline & & 4 & 3 & 2 & 1 \\
\hline 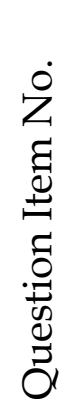 & Question & 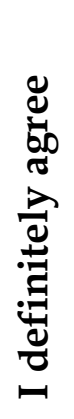 & 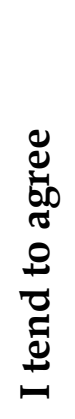 & 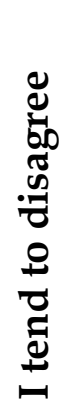 & 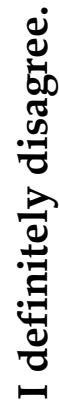 \\
\hline 1. & $\begin{array}{l}\text { I am fully aware that by the time I graduate } \\
\text { from ACTEP, my IELTS score result needs to } \\
\text { be } 5.5 \text { on overall band. }\end{array}$ & & & & \\
\hline 2. & $\begin{array}{l}\text { I am fully aware of the format of the IELTS } \\
\text { Academic exam. }\end{array}$ & & & & \\
\hline 3. & $\begin{array}{l}\text { My CU-TEP score in the listening section has } \\
\text { reflected/ will reflect my present listening } \\
\text { ability. }\end{array}$ & & & & \\
\hline 4. & $\begin{array}{l}\text { My CU-TEP score in the reading section has } \\
\text { reflected/ will reflect my present reading } \\
\text { ability. }\end{array}$ & & & & \\
\hline 5. & $\begin{array}{l}\text { My CU-TEP score in the writing section has } \\
\text { reflected/ will reflect my present writing } \\
\text { ability. }\end{array}$ & & & & \\
\hline 6. & The 4-skill English course has helped/ will & & & & \\
\hline
\end{tabular}




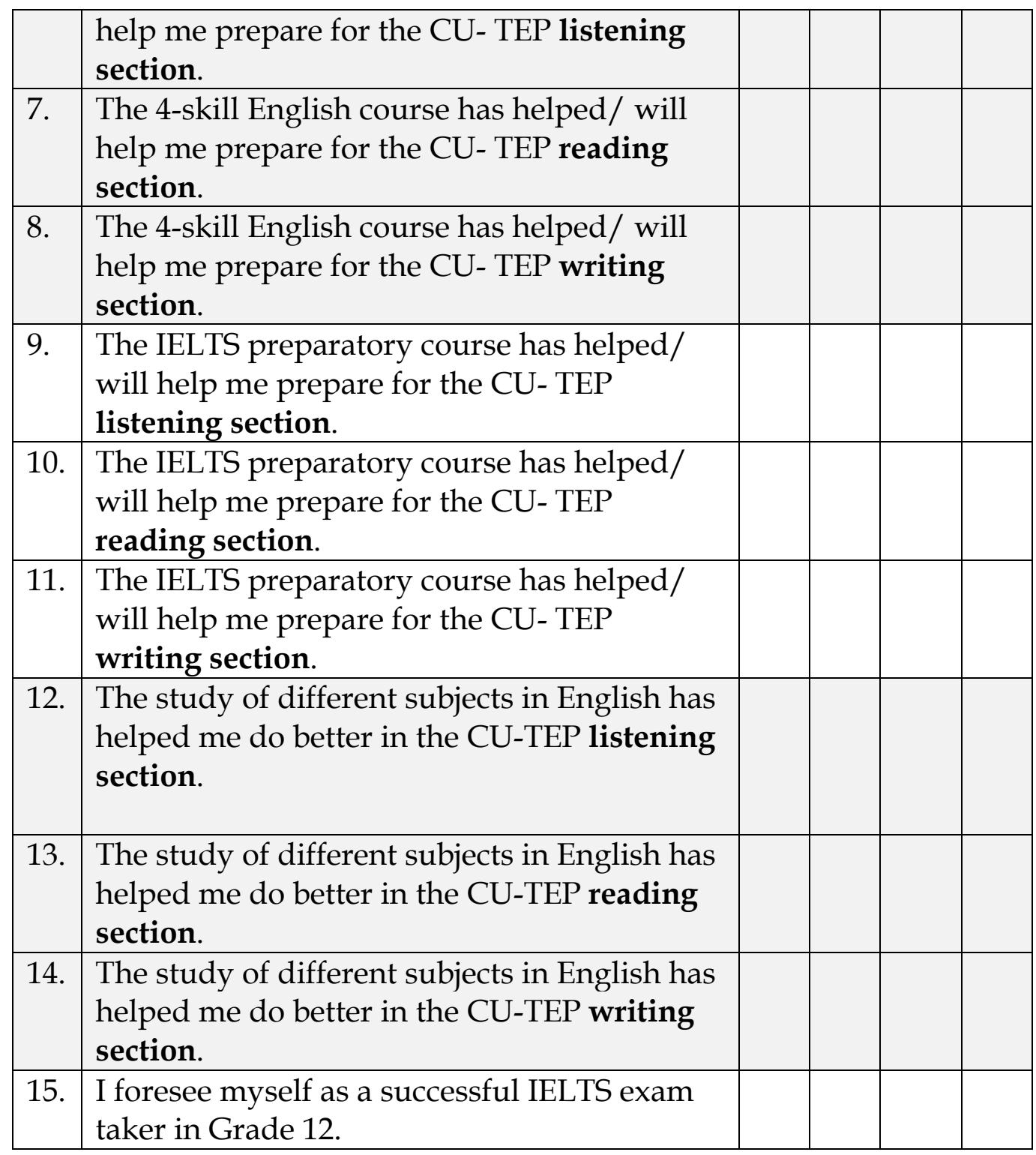

Comments.

\section{Findings}

The following table shows the findings from the questionnaire for ACTEP

Grades 10-11 students.

\begin{tabular}{|l|l|l|l|l|l|l|}
\hline a & 4 & 3 & 2 & 1 & 0 \\
\hline
\end{tabular}




\begin{tabular}{|c|c|c|c|c|c|c|c|c|c|c|c|}
\hline & \multirow[t]{2}{*}{ Question } & \multicolumn{2}{|l|}{ 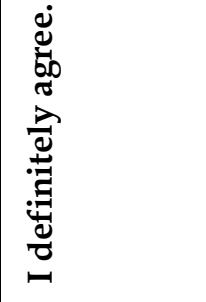 } & \multicolumn{2}{|l|}{ 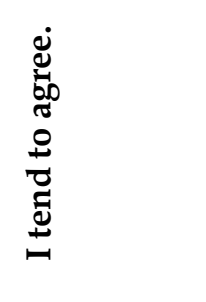 } & \multicolumn{2}{|l|}{ 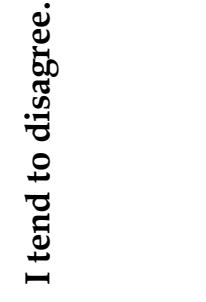 } & \multicolumn{2}{|c|}{ 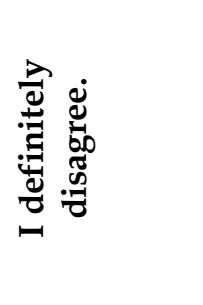 } & \multicolumn{2}{|l|}{ 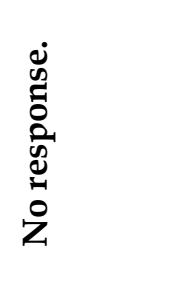 } \\
\hline & & G.10 & G.11 & G.10 & G.11 & G.10 & G.11 & G.10 & G.11 & G.10 & G.11 \\
\hline 1. & $\begin{array}{l}\text { I am fully } \\
\text { aware that by } \\
\text { the time I } \\
\text { graduate from } \\
\text { ACTEP, my } \\
\text { IELTS score } \\
\text { result needs to } \\
\text { be } 5.5 \text { on } \\
\text { overall band. }\end{array}$ & 15 & 18 & 21 & 18 & 30 & 2 & 0 & 2 & 1 & 2 \\
\hline 2. & $\begin{array}{l}\text { I am fully } \\
\text { aware of the } \\
\text { format of the } \\
\text { IELTS } \\
\text { Academic } \\
\text { exam. }\end{array}$ & 13 & 21 & 14 & 4 & 8 & 13 & 3 & 0 & 1 & 0 \\
\hline 3. & $\begin{array}{l}\text { My CU-TEP } \\
\text { score in the } \\
\text { listening } \\
\text { section has } \\
\text { reflected/ will } \\
\text { reflect my } \\
\text { present } \\
\text { listening } \\
\text { ability. }\end{array}$ & 9 & 10 & 22 & 22 & 6 & 6 & 2 & 0 & 0 & 0 \\
\hline 4. & $\begin{array}{l}\text { My CU-TEP } \\
\text { score in the } \\
\text { reading section } \\
\text { has reflected/ } \\
\text { will reflect my } \\
\text { present } \\
\text { reading ability. }\end{array}$ & 10 & 10 & 23 & 21 & 4 & 7 & 2 & 0 & 0 & 0 \\
\hline 5. & $\begin{array}{l}\text { My CU-TEP } \\
\text { score in the } \\
\text { writing section } \\
\text { has reflected/ } \\
\text { will reflect my } \\
\text { present writing } \\
\text { ability. }\end{array}$ & 7 & 13 & 25 & 21 & 7 & 4 & 0 & 0 & 0 & 0 \\
\hline 6. & $\begin{array}{l}\text { The 4-skill } \\
\text { English course } \\
\text { has helped/ } \\
\text { will help me } \\
\text { prepare for the } \\
\text { CU- TEP } \\
\text { listening }\end{array}$ & 5 & 8 & 23 & 20 & 10 & 9 & 1 & 1 & 0 & 0 \\
\hline
\end{tabular}




\begin{tabular}{|c|c|c|c|c|c|c|c|c|c|c|c|}
\hline \multirow[b]{3}{*}{ 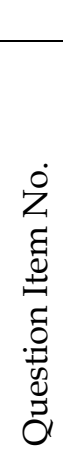 } & \multirow[b]{3}{*}{ Question } & \multirow{2}{*}{\multicolumn{2}{|c|}{4}} & & & & & & & & \\
\hline & & & & \multicolumn{2}{|c|}{3} & \multicolumn{2}{|c|}{2} & \multicolumn{2}{|c|}{1} & \multicolumn{2}{|c|}{0} \\
\hline & & 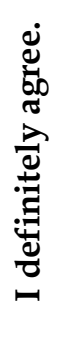 & & 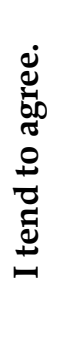 & & 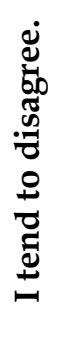 & & 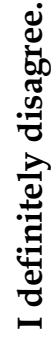 & & 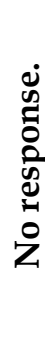 & \\
\hline 7. & $\begin{array}{l}\text { The 4-skill English } \\
\text { course has helped/ } \\
\text { will help me prepare } \\
\text { for the CU- TEP } \\
\text { reading section. }\end{array}$ & 4 & 10 & 25 & 20 & 9 & 6 & $\overline{1}$ & 2 & 0 & 0 \\
\hline 8. & $\begin{array}{l}\text { The 4-skill English } \\
\text { course has helped/ } \\
\text { will help me prepare } \\
\text { for the CU- TEP } \\
\text { writing section. }\end{array}$ & 7 & 8 & 18 & 23 & 11 & 5 & 3 & 2 & 0 & 0 \\
\hline 9. & $\begin{array}{l}\text { The IELTS } \\
\text { preparatory course } \\
\text { has helped/ will help } \\
\text { me prepare for the } \\
\text { CU-TEP listening } \\
\text { section. }\end{array}$ & 6 & 13 & 23 & 18 & 9 & 6 & 1 & 1 & 0 & 0 \\
\hline 10 & $\begin{array}{l}\text { The IELTS } \\
\text { preparatory course } \\
\text { has helped/ will help } \\
\text { me prepare for the } \\
\text { CU- TEP reading } \\
\text { section. }\end{array}$ & 6 & 12 & 14 & 20 & 17 & 6 & 2 & 0 & 0 & 0 \\
\hline 11 & $\begin{array}{l}\text { The IELTS } \\
\text { preparatory course } \\
\text { has helped/ will help } \\
\text { me prepare for the } \\
\text { CU- TEP writing } \\
\text { section. }\end{array}$ & 9 & 14 & 19 & 19 & 9 & 4 & 2 & 0 & 0 & 1 \\
\hline 12 & $\begin{array}{l}\text { The study of different } \\
\text { subjects in English } \\
\text { has helped me do } \\
\text { better in the CU-TEP } \\
\text { listening section. }\end{array}$ & 15 & 15 & 14 & 16 & 9 & 6 & 1 & 1 & 0 & 0 \\
\hline 13 & $\begin{array}{l}\text { The study of different } \\
\text { subjects in English } \\
\text { has helped me do } \\
\text { better in the CU-TEP } \\
\text { reading section. }\end{array}$ & 8 & 15 & 22 & 16 & 8 & 7 & 1 & 0 & 0 & 0 \\
\hline 14 & $\begin{array}{l}\text { The study of different } \\
\text { subjects in English } \\
\text { has helped me do } \\
\text { better in the CU-TEP } \\
\text { writing section. }\end{array}$ & 7 & 14 & 22 & 20 & 9 & 4 & 1 & 0 & 0 & 0 \\
\hline 15 & I foresee myself as a & 10 & 7 & 15 & 25 & 8 & 4 & 3 & 1 & 3 & 1 \\
\hline
\end{tabular}




\begin{tabular}{|l|l|l|l|l|l|l|l|l|l|l|l|}
\hline$\cdot$ & $\begin{array}{l}\text { successful IELTS } \\
\text { exam taker in Grade } \\
12 .\end{array}$ & & & & & & & & & & \\
\hline
\end{tabular}

In regards to the students' awareness of the fact they are required to possess a minimum score result of IELTS 5.5 on overall band by the time they graduate from ACTEP, there are 89.74 percent of the Grade 10 students and 94.74 percent of the Grade 11 students who definitely agree or tend to agree to this fact.

Regarding how the four-skill English course has helped them prepare for the CU-TEP listening, reading and writing, 70.08 percent of Grade 10 students on average and 78.07 percent of Grade 11 students on average definitely agree or tend to agree with it.

On average 65.81percent of Grade 10 students and 84.21 percent of Grade 11 students definitely agree or tend to agree that the IELTS preparatory course has helped them prepare for the CU-TEP listening, reading and writing section.

On average 64.10 percent of Grade 10 students and 84.21 percent of Grade 11 students foresee themselves as a successful IELTS exam taker when in Grade 12 at ACTEP.

It can be clearly seen that IELTS has influenced the ways the four-skill courses and the IELTS preparatory courses offered at ACTEP. At the same time, these English courses have brought more confidence to students in sitting CU-TEP and IELTS. 


\section{Washbacks of IELTS on Teachers' Teaching}

The requirement which says that by the end of Grade 12 all EP students are expected to be able to pass the IELTS score 5.5 on overall band is announced to all ACTEP foreign teachers who teach classes in ACTEP at the beginning of the academic year 2010. Teachers of non-English subjects like Mathematics, Science and Home Economics are encouraged to utilize a variety of communication skills to widen the students' experience in using English based on different content, which is expected to contribute to the students' success on their IELTS taking.

\section{Data Collection}

In studying how IELTS has brought its impact to ACT teachers' teaching, ACTEP foreign teachers were all given a questionnaire. Table 7 shows how long each teacher who answered the questionnaire in the study has been working for ACTEP.

Table 7

ACTEP Foreign Teachers in the Study's Length of Employment

\begin{tabular}{|c|l|l|c|}
\hline No. & \multicolumn{1}{|c|}{ Subject } & \multicolumn{1}{|c|}{ Grade } & $\begin{array}{c}\text { Length of } \\
\text { Employment } \\
\text { (Month) }\end{array}$ \\
\hline 1 & Non-English & Grades 1-6 & 24 \\
\hline 2 & Non-English & Grades 3-4 & 18 \\
\hline 3 & Non-English & Grades 5-6 & 3 \\
\hline 4 & Non-English & Grades 5-6 & 19 \\
\hline 5 & Non-English & Grades 7-11 & 10 \\
\hline 6 & Non-English & Grades 9-10 & 9 \\
\hline 7 & Non-English & Grades 10-11 & 3 \\
\hline 8 & Non-English & Grades 11 & 3 \\
\hline & & & $\begin{array}{c}\text { Length of } \\
\text { Employment } \\
\text { (Month) }\end{array}$ \\
\hline No. & Subject & Grade & \multicolumn{2}{c|}{} \\
\hline
\end{tabular}




\begin{tabular}{|c|l|l|l|}
\hline 9 & English & Grades 1-2 & 4 \\
\hline 10 & English & Grades 3-4 & 3 \\
\hline 11 & English & Grades 5-6 & 8 \\
\hline 12 & English & Grades 7-8 & 6 \\
\hline 13 & English & Grades 7-8 & 9 \\
\hline 14 & English & Grades 10-11 & 4 \\
\hline
\end{tabular}

14 out of 26 questionnaires as shown below were collected from 8 NonEnglish subject teachers and 6 English subject teachers.

\section{Questionnaire for Assumption College Thonburi English Program (ACTEP)}

\section{teachers}

This questionnaire is to find out how the following facts are perceived by ACTEP teachers.

1. All of the students are required to pass either TOEFL at the score of 550 (paper-based) or IELTS at the score of 5.5 on overall band during your Grade 12 study at Assumption College Thonburi can have an impact on their study in the English Program at Assumption College Thonburi.

\section{CU-TEP (Chulalongkorn University Test of English Proficiency)} is used as the main English proficiency test in Grades 10-11 in the academic year 2009 and 2010.

3. The ways that different subjects including Mathematics, Basic Science, Additional Science, Health and Physical Education, Music and Career and Technology are taught in English and that English courses are designed by having Class A (Science-Maths students) take a 4-skill English course (5 periods/week) and an IELTS preparatory course (2 periods/week) and having Class B (Maths-English students) take a 4-skill English course (5 periods/week), an IELTS preparatory course (2 periods/week), and an 
academic writing course (4 periods/week) during regular classes MondaysFridays.

Please answer these background questions:

1. I have been teaching at ACTEP for years and months.

2. List your teaching experience so far

In Thailand years months

Outside Thailand years months

3. Please circle the subject you have been teaching at ACTEP

English Non-English

4. Please write down the level(s) you have been teaching at ACTEP in the Academic year 2010 (from May 2010- April 2011)

\begin{tabular}{|c|c|c|c|c|c|}
\hline & \multirow[b]{2}{*}{ Question } & 4 & 3 & 2 & 1 \\
\hline 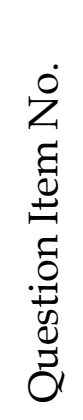 & & 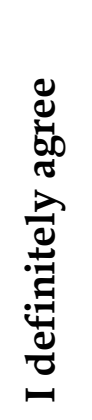 & 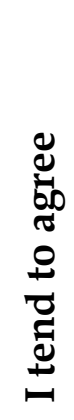 & 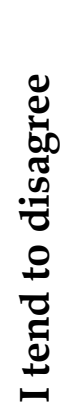 & 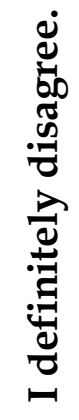 \\
\hline 1. & $\begin{array}{l}\text { I am fully aware that by the time the students } \\
\text { graduate from ACTEP, their IELTS score result } \\
\text { needs to be } 5.5 \text { on overall band. }\end{array}$ & & & & \\
\hline 2. & $\begin{array}{l}\text { I am fully aware of the format of the CU-TEP } \\
\text { exam. }\end{array}$ & & & & \\
\hline 3. & $\begin{array}{l}\text { I am fully aware of the format of the IELTS } \\
\text { Academic exam. }\end{array}$ & & & & \\
\hline & $\begin{array}{l}\text { In teaching my subject, I practice with students } \\
\text { the following skills }\end{array}$ & & & & \\
\hline & Listening Skills & & & & \\
\hline
\end{tabular}




\begin{tabular}{|l|l|l|l|l|l|}
\hline 4. & Understanding the instruction & & & & \\
\hline 5. & Previewing and Predicting & & & & \\
\hline 6. & Listening for specific information & & & & \\
\hline 7. & Checking and rewriting & & & & \\
\hline & Reading Skills & & & & \\
\hline 8. & Previewing & & & & \\
\hline 9. & Interpreting the instructions and questions & & & & \\
\hline 10. & Scanning the text for specific answers & & & & \\
\hline 11. & Checking their answers & & & & \\
\hline & Writing Skills & & & & \\
\hline 12. & Preparation & & & & \\
\hline 13. & Writing & & & & \\
\hline 14. & Editing & & & & \\
\hline & Speaking Skills & & & & \\
\hline 15. & Introduction and interview & & & & \\
\hline 16. & Individual long run (extended speaking) & & & & \\
\hline 17. & Two-way discussion & & & \\
\hline
\end{tabular}

Comments.

\section{Findings}

The findings can be shown as below.

\begin{tabular}{|c|c|c|c|c|c|c|}
\hline & & 4 & 3 & 2 & 1 & 0 \\
\hline 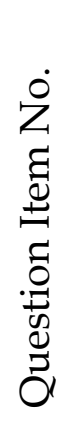 & Question & 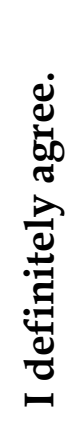 & 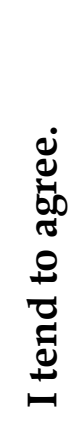 & 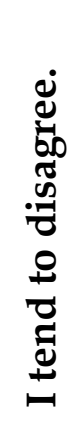 & 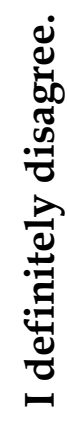 & 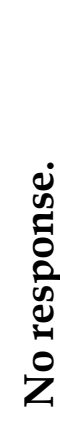 \\
\hline 1. & $\begin{array}{l}\text { I am fully aware that by the time the } \\
\text { students graduate from ACTEP, their } \\
\text { IELTS score result needs to be } 5.5 \text { on } \\
\text { overall band. }\end{array}$ & 5 & 7 & 1 & 1 & 0 \\
\hline 2. & $\begin{array}{l}\text { I am fully aware of the format of the CU- } \\
\text { TEP exam. }\end{array}$ & 4 & 2 & 3 & 5 & 0 \\
\hline
\end{tabular}




\begin{tabular}{|l|l|l|l|l|l|l|}
\hline 3. & $\begin{array}{l}\text { I am fully aware of the format of the } \\
\text { IELTS Academic exam. }\end{array}$ & 6 & 4 & 3 & 1 & 0 \\
\hline & $\begin{array}{l}\text { In teaching my subject, I practice with } \\
\text { students the following skills }\end{array}$ & & & & & \\
\hline & Listening Skills & & & & & \\
\hline 4. & Understanding the instruction & 12 & 1 & 0 & 1 & 0 \\
\hline 5. & Previewing and Predicting & 10 & 4 & 0 & 0 & 0 \\
\hline 6. & Listening for specific information & 11 & 1 & 0 & 1 & 0 \\
\hline 7. & Checking and rewriting & 11 & 3 & 0 & 0 & 0 \\
\hline & Reading Skills & & & & & \\
\hline 8. & Previewing & 8 & 5 & 1 & 0 & 0 \\
\hline 9. & $\begin{array}{l}\text { Interpreting the instructions and } \\
\text { questions }\end{array}$ & 12 & 1 & 1 & 0 & 0 \\
\hline 10. & Scanning the text for specific answers & 11 & 3 & 0 & 0 & 0 \\
\hline 11. & Checking their answers & 12 & 0 & 1 & 0 & 1 \\
\hline & Writing Skills & & & & & \\
\hline 12. & Preparation & 7 & 6 & 1 & 0 & 0 \\
\hline 13. & Writing & 6 & 7 & 1 & 0 & 0 \\
\hline 14. & Editing & 7 & 5 & 2 & 0 & 0 \\
\hline & Speaking Skills & & & & & \\
\hline 15. & Introduction and interview & 7 & 7 & 0 & 0 & 0 \\
\hline 16. & Individual long run (extended speaking) & 3 & 10 & 1 & 0 & 0 \\
\hline 17. & Two-way discussion & 6 & 8 & 0 & 0 & 0 \\
\hline
\end{tabular}

On average, the teachers were well advised of the fact that ACTEP Grade 12 students are going to take IELTS and have to demonstrate English competence of the minimum IELTS 5.5 on overall band. There are 42.86 percent of the teachers who definitely agree or tend to agree that they are aware of the format of the CU-TEP exam while there are 71.43 percent of teachers who definitely agree or tend to agree that they are aware of the format of the IELTS exam.

The vast majority of the teachers definitely agree or tend to agree that they practice with the students the following skills in their teaching.

- Understanding the instruction

- $\quad$ Listening for specific information 
- $\quad$ Previewing

- Interpreting the instructions and questions

- $\quad$ Checking their answers

- Preparation

- Writing

- $\quad$ Editing

- Individual long run

All of the teachers definitely agree or tend to agree that they practice with the students the following skills in their teaching.

- $\quad$ Previewing and Predicting

- $\quad$ Checking and Rewriting

- $\quad$ Scanning the text for specific answers

- Introduction and interview

- Two-way discussion

As demonstrated by the data collected, IETLS has provided beneficial washback to the teachers' teaching at ACTEP.

\section{Discussion and Recommendations}

1. From the finding, 82.05 percent of Grade 10 students on average and 85.09 percent of Grade 11 students on average definitely agree or tend to agree that CU-TEP can reflect their listening, reading and writing skills. However, from the fact that CU-TEP has no speaking test. IELTS mock speaking test is recommended for Grade10 and 11 twice a semester and is included in formative assessment every semester. In addition, the students 
need to be advised that the writing section in CU-TEP is not the same as that of the IELTS which asks them to write an actual academic essay.

2. A critical analysis of the students' CU-TEP scores is conducted and the results are discussed mainly among teachers of English for an adjustment of their teaching strategies and planning at the very beginning of every school year.

3. CU-TEP writing cannot reflect all strategies needed in IELTS writing test. This needs to be clarified to the students with IELTS writing sample questions. Students need to practice more during their Grads 10- 11 English years.

4. What is revealed in the data collected from the questionnaires for students is that more than $94.87 \%$ of Grade 10 students plan to attend an International Program, $37.83 \%$ of them to Mahidol University International Program and $32.43 \%$ of them to Chulalongkorn University and that more than $86.84 \%$ of Grade 11 students plan to attend an International Program, 51.51\% of them to Mahidol University and $42.42 \%$ of them to Chulalongkorn University; reconsideration of the cut-off IELTS scores is needed. From the Mahidol University website, applicants to Mahidol University International Program are required to pass IELTS at the score of 6.5 on overall band with at least 6.0 on the writing band.

5. Teachers are one of the main factors of students' success due to the fact that they provide language input and practice with the students on different strategies needed for IELTS. Considerations should be taken for a 
training workshop by IELTS examiners to provide more insights to IELTS test format as shown from the finding of the students' questionnaire that only 33.33 percent of Grade 10 and 55.26 percent of Grade 11 know exactly what the IELTS format is like. It is also recommended that enough IELTS practice books and IELTS guidebooks are well stocked in the English teachers' resource room or conor. Samples of questions from the IELTS Listening Module, the IELTS Reading Module, the IELTS Writing Module and the Speaking Modules along with how each module assess its examinee with each rubrics should also be well explained to the students.

6. If possible, both core English courses and supplementary courses should be IELTS-oriented. According to three of the Grade 11 students who went on the UK study tour to take an 8-week IELT preparatory course and passed the score of 5.5 when they were in Grade 10 said almost the same thing like "I can do better with IELTS if I am focusing on the test at least 3 hours a day like when I was in the UK".

7. From the finding, on average 76.21 percent of Grade 10 students and 84.21 percent of Grade 11 students definitely agree or tend to agree that the study of different subjects in English has helped them do better in the CUTEP listening, reading and writing sections. Therefore, if possible teachers of non-English subjects such as mathematics should be advised that their English input is as important as that of the English teacher's input. Involving them in an IELTS seminar or showing them sample models of IELTS exams 
could be done at the beginning of every school year or semester and would be a great idea.

8. English-speaking activities should be offered more to students. This can help students learn to use the language in a wider range of experiences.

\section{References}

Bemmel, E. \& Tucker, J. (2011). IELTS to success: Preparation tips and practice tests (3rd ed.). Queensland: John Wiley \& SonsAustralia.

Chulalongkorn University Language Institute (CULI) (2004). Chulalongkorn University Test of English Proficiency (CU-TEP) Practice Test (rev. ed.). Bangkok: Chulalongkorn University Printing House.

Hallows, R., Lisboa, M. \& Unwin, M. (2006). IELTS Express Intermediate. London: Thomson ELT.

Mahidol University International College. (2011, February). Admission Requirements. Retrieved from http://www.muic.mahidol.ac.th/eng/?page_id=1633

Mitchell, H. Q. (2009). Traveller level intermediate B1 student's book. The EU: MM Publications. 